\title{
Postkolonializm i środkowoeuropejska nowoczesność
}

\author{
EMILIA KLEDZIK ${ }^{1}$ \\ (Uniwersytet im. A. Mickiewicza w Poznaniu)
}

Piętnaście lat, które upłynęło od publikacji fundatorskiego dla środkowoeuropejskich studiów postkolonialnych tekstu amerykańskiego badacza węgierskiego pochodzenia Davida Chioniego Moore'a pt. Is the Post- in Postcolonial the Post- in Postsoviet? na łamach wpływowego pisma wydawanego przez Modern Language Association, zdezaktualizowało jego najważniejsze tezy. Moore pisał wtedy o podwójnym milczeniu, jakie spowija kraje niegdyś kontrolowane przez Sowietów, związanym z ich potencjalną postkolonialnością: po pierwsze, leżący za oceanem mainstream studiów postkolonialnych milczał, jego zdaniem, na temat tej części świata, a po drugie - badacze wywodzący się z regionu wykazywali się - jak to ujmował - „nieumiejętnością myślenia o swoich regionach w kategoriach przydatnych, jeśli nie ze wszech miar idealnych pojęć, rozwiniętych przez badaczy z Indonezji lub Gabonu" (Moore 117). Tamten tekst kierowany był przede wszystkim do amerykańskich slawistów, zaś dwa lata później do polskich humanistów zwróciła się amerykańska polonistka, tłumaczka Wisławy Szymborskiej i Czesława Miłosza, uczennica Stanisława Barańczaka, Clare Cavanagh, pisząc na łamach „Tekstów Drugich" o postkolonializmie jako białej plamie na mapie polskiej teorii. Dwie grupy, do których kierowane były wymienione apele, nadal, jak się wydaje, nie mówią jednym głosem w podstawowej kwestii, a mianowicie wniosków, jakie dla naszego regionu wypływają z kompatybilności doświadczenia postsowieckiego i postkolonialnego. Ci pierwsi domagają się przede wszystkim mocniejszego głosu studiów polonistycznych/slawistycznych/środkowoeuropejskich na forum amerykańskiej humanistyki, i widzą w postkolonialności tych obszarów szansę na skupienie większej uwagi na obszarze, który po upadku żelaznej kurtyny cieszy się mniejszym zainteresowaniem amerykańskiej Akademii. Lokalni badacze natomiast, o ile bliska jest im ta perspektywa, używają postkolonialności przede wszystkim w roli nowego kodu tożsamościowego, konkurencyjnego dla narracji

\footnotetext{
${ }^{1}$ Correspondence Address: emilia.kledzik@gmail.com
} 
martyrologicznej i innych mitów, będących schedą po językach romantyzmu. Polska/środkowoeuropejska postkolonialność okazała się zaskakująco chłonną kategorią, w której mieszczą się zarówno rewizje ambicji kolonizatorskich, doświadczenia zaborów i przesiedleń, a także diagnozy związane z ostatnim przyspieszeniem modernizacyjnym. Łączy je, podkreślam, przekonanie, że bycie subalternem/kolonizatorem to nieskonceptualizowana dotąd część tożsamości środkowoeuropejskiej, która może być porównana, choć raczej w myśl niemieckiej zasady „Vergleich ist keine Gleichsetzung”, z doświadczeniem mieszkańców innych części świata. Dziś można chyba stwierdzić, że postkolonializm stał się jednym z najważniejszych języków, jakimi polscy humaniści mówią o środkowo-europejskim zderzeniu z nowoczesnością i jakimi dokonują rewizji pisania historii, w tym historii literatury, po blisko pięciu dziesięcioleciach sowieckiej dominacji. Co więcej, polska/środkowoeuropejska postkolonialność, choć wyjściowo, zgodnie z apelem Cavanagh, miała zajmować przede wszystkim literaturoznawców, po czasie przeniknęła do języka publicystyki i debaty politycznej, a nawet stała się narzędziem jej polaryzacji. Jak zdarzyło się to również w przypadku Europy Zachodniej i jej dawnych dominiów, teoria wyprzedziła praktykę literacką i stała się impulsem do powstania utworów, które traktują o tej zdredefiniowanej polskiej/środkowoeuropejskiej tożsamości.

Nie może więc zaskakiwać, że w niniejszym tomie „Porównań”, który jest już dziesiątym z kolei poświęconym w całości lub częściowo problemom komparatystyki postkolonialnej w Europie Środkowej, stosunkowo niewiele miejsca poświęcają autorzy samej literaturze. Specyfika lokalnych rozważań nad postkolonialnością polega bowiem na tym, iż rzadko jest ona rzeczywistym, czyli umocowanym estetycznie, przedmiotem zainteresowania piszących. Bywa, że staje się to przedmiotem zdecydowanej krytyki badaczy opowiadających się po stronie fenomenologii dzieła literackiego, jak w prezentowanym tekście serbskiego badacza Slobodana Vladušicia. Zdarza się jednak, że - jak w przypadku artykułu Borisa Škvorca na temat powieści Ivo Andricia - postkolonialna diagnoza nie wychodzi poza granice utworu literackiego, w którym odbija się specyficzny lokalny porządek kolonialny, a jednocześnie - za sprawą nieuniknionej fikcjonalności tekstu - ulega on podważeniu, dekonstrukcji. Polaryzację dyskursów postkolonialności można by równie dobrze wytyczyć w inny sposób: przebiegałaby ona pomiędzy apelem Ewy Thompson z mocną tezą o studiach polonistycznych/środkowoeuropejskich jako nowej białej plamie na mapie amerykańskich studiów slawistycznych a analizą publicystyki Roberta Ziemkiewicza, diagnozującej konsekwencje niewątpliwej i wielokrotnej z punktu widzenia autora Polactwa kolonizacji dla „duszy polskiej” pióra Tomasza Nakonecznego. Trudno orzec, które z tych tekstów są najmocniej osadzone w paradygmacie postkolonialnym. Wszystkie używają postkolonialnego kodu do konceptualizacji doświadczenia konfrontacji z (dyskursywną) władzą. Tytuł konferencji, której pokłosie częściowo prezentujemy w niniejszym tomie, 
a która odbyła się w Instytucie Filologii Polskiej Uniwersytetu im. Adama Mickiewicza w Poznaniu 2-3 czerwca 2014 roku, brzmiał "Języki postkolonialności w Europie Środkowej i Wschodniej: kultura, życie społeczne i polityczne po 1989 roku". Nacisk na tę postkolonialną polifonię leżał na sercu organizatorom tej konferencji i jest przedmiotem troski redaktorów „Porównań".

Niniejszy numer otwiera wspomniany powyżej tekst Ewy Thompson, w którym pada oskarżenie pod adresem amerykańskich uniwersytetów o faworyzowanie rusycystyki i ignorowanie środkowoeuropejskich filologii narodowych. "Niewidzialność" tych studiów przejawia się w szeregu praktyk związanych $z$ organizacją życia naukowego, esencjalizującym stosunkiem do badaczy wywodzących się z tej części świata i prowadzi do utrwalenia szkodliwych stereotypów, nierzadko, zdaniem Autorki, zaskakująco zbieżnych z ideologią sowiecką i putinowską. Artykuły Arenta Nieukerkena i Marka Jedlińskiego dotykają zagadnienia dyskursu neoazjatyzmu w stosunku do Europy Środkowej i Wschodniej. Pierwszy mówi o mitach fundacyjnych związanych z Rusią Kijowską w kontekście ideologicznej wykładni konfliktu rosyjsko-ukraińskiego. Drugi zajmuje się Aleksandrem Duginem, jednym z najbardziej wpływowych współczesnych rosyjskich „mitografów politycznych".

Dział poświęcony postkolonialnym Bałkanom, który nie powstałby bez zaangażowania dr hab. Sylwii Nowak-Bajcar, oddaje w pełni różnorodność języków postkolonializmu, jakimi mówi Europa Środkowa. Tekst Slobodana Vladušicia dystansuje się od literackiej wykładni postkolonialnej, nazywając ją „inkwizytorską", choć wskazuje możliwe ścieżki jej absorbcji, w tym twórczość hybrydyczną. Artykuł Igora Perišicia proponuje czytanie postkolonialne przeciwko eksperymentom postmodernistycznym, wskazuje na jego potencjał terapeutyczny i jako egzemplum proponuje trop zwierzęcych paraboli w najnowszej prozie serbskiej. Tatjana Rosić prezentuje zagadnienie pisarstwa kobiet w Serbii, przestawiając figurę kobiety-cyborga, konkurencyjną wobec komercjalizacji kategorii literatury kobiecej, a nawet niebezpieczną z punktu widzenia patriarchalnego status quo, podtrzymywanego przez krytykę i publiczność czytelniczą. Boris Škvorc dokonuje mistrzowskiej interpretacji powieści Ivo Andricia pt. Most na Drinie, wskazując i dekonstruując głos tekstowych instancji i ich umiejscowienie w grze o władzę i wynikającą z niej specyfikę bośniackiej postkolonialności: zawłaszczanej przez Orient i Okcydent. Magdalena Koch, korzystając z kategorii „mikrohistorii” Ewy Domańskiej, odtwarza prywatne, kobiece doświadczenie Wielkiej Wojny, zawarte w twórczości Milicy Jakovljević.

Znakomity tekst Dariusza Skórczewskiego poświęcony kategorii strachu w filmach Wojciecha Smarzowskiego jest ważnym głosem o artystycznych emanacjach kolonialnej traumy i - szerzej - o przejawiającej się w grozie tych obrazów polskiej mentalności postkolonialnej. Ta z kolei jest przedmiotem zainteresowania polskiego publicysty, Rafała Ziemkiewicza, którego rozważania nad alternatywą 
wobec metropolitalnej nowoczesności w sposób wolny od negatywnych stereotypów „endeckości” prezentuje w niniejszym tomie Tomasz Nakoneczny. O niej również w swoisty sposób traktuje tekst Elizy Grzelakowej, dotykający ważkiego zagadnienia komunikacji pomiędzy społeczeństwem większościowym a mniejszościami narodowymi i etnicznymi w Polsce. Wypływa z niego smutny wniosek, że utrwalona w pamięci społecznej kolonialna trauma w znaczący sposób wpłynęła na stosunek Polaków wobec inności, czego ilustracją są liczne prezentowane werbalne i niewerbalne zachowania komunikacyjne.

Jak wynika z rozważań prezentowanych $\mathrm{w}$ niniejszym tomie autorek i autorów, najważniejszym bodaj językiem postkolonialności w Europie Środkowej i Wschodniej jest dyskurs społecznej diagnozy stawianej w perspektywie ostatniego przełomu politycznego. Nie jest nim literatura, choć wypada się spodziewać, że i ona zapewne - jak uczy przykład innych społeczeństw postkolonialnych wkrótce opowie o tym doświadczeniu na własny, subwersywny i nieoczywisty sposób.

\section{BIBLIOGRAFIA}

Moore David Chioni. „Is the Post- in Postcolonial the Post- in Post-soviet? Toward a Global Postcolonial Critique". PMLA 116 (2001).

Cavanagh Clare. „Postkolonialna Polska. Biała plama na mapie współczesnej teorii”. Teksty Drugie 2/3 (2003). 